\title{
Distribution of meiobenthos at bathyal depths in the Mediterranean Sea. A comparison between sites of contrasting productivity*
}

\author{
ANASTASIOS TSELEPIDES, NIKOLAOS LAMPADARIOU \\ and ELENI HATZIYANNI \\ Institute of Marine Biology, Hellenic Centre for Marine Research, Gournes Pediados, P.O. Box 2214, 71003 Heraklion, \\ Crete, Greece. E-mail: ttse@imbc.gr
}

\begin{abstract}
SUMMARY: In order to study the distribution of meiobenthos (Metazoa and Foraminifera) at bathyal depths along a westeast productivity gradient in the Mediterranean Sea, stations along the continental slopes of the Balearic Sea, west Ionian and east Ionian Seas were sampled during the DESEAS Trans-Mediterranean Cruise in June-July 2001. Standing stock of total meiobenthos differed considerably among the sampling stations, with marked differences occurring between sampling depths and sites. At $600 \mathrm{~m}$ depth, meiobenthic abundances were slightly higher over the Balearic continental slope, whereas at the deeper stations ( $800 \mathrm{~m}$ and 1500-1700 m), abundances were significantly higher in the west Ionian Sea. Significant relationships were found between the abundances of major groups and the chloroplastic pigments, indicating that food availability is a major factor controlling the distribution of meiobenthos. Apart from the overall differences in productivity between the western and eastern Mediterranean Sea, local hydrographic features and topographic differences greatly influence the spatial variability of the environmental parameters within each sub-basin and thus the distribution of meiobenthos in the bathyal zone.
\end{abstract}

Key words: meiobenthos, deep-sea, bathyal, Mediterranean Sea, Balearic Sea, Ionian Sea.

RESUMEN: DisTRIBUCión DEL MEIOBENTOS EN FONDOS BATIALES DEL MEDITERRÁNEO: UNA COMPARACIÓN ENTRE LUGARES DISTANTES. - Para el estudio del meiobenthos (Metazoa y foraminifera) en los fondos batiales del Mediterráneo a lo largo del gradiente de productividad oeste-este, se hicieron muestreos en la plataforma continental del mar Balear y del mar Iónico oriental y occidental, durante la campaña transmediterránea DESEAS (junio-julio, 2001). La biomasa permanente del meiobentos total difiere considerablemente entre las muestras de las distintas estaciones y profundidades. A $600 \mathrm{~m}$ de profundidad las abundancias de meiobentos fueron un poco más altas en la plataforma de Baleares, mientras que en las estaciones más profundas (800 y 1500-1700 m), las abundancias fueron significativamente más altas en el Iónico occidental. Se encontraron relaciones significativas entre las abundancias de los grupos mayoritarios y los pigmentos cloroplásticos, indicando que la disponibilidad de alimento es el principal factor que controla la distribución del meiobentos. Aparte de las diferencias globales entre la productividad del Mediterráneo oriental y occidental, son las características hidrográficas y las diferencias topográficas quienes influencian fuertemente en la variabilidad espacial de los parámetros ambientales en cada sub-cubeta, y por tanto, en la distribución del meibentos en la zona batial.

Palabras clave: meiobentos, mar profundo, batial, mar Mediterráneo, mar Balear, mar Jónico.

\section{INTRODUCTION}

The Mediterranean Sea, one of the most oligotrophic basins in the world, is characterised by a

*Received February 15, 2003. Accepted February 10, 2004. west-east productivity gradient because of the hydrographic differences between its two subbasins, the different productivity levels in the surface waters and the variability in vertical fluxes of organic carbon to the seafloor (Danovaro et al., 1999). Inflows from the Gibraltar Straits, river inputs and 
water exchanges in the Sicily Straits cause an asymmetry in the nutrient loads, forming gradients in nutrient and productivity levels (Crispi et al., 2001). Nutrient and water exchanges between the western and eastern basins are highly dynamic, influencing the biogeochemistry and the overall productivity of the ecosystem (Bethoux et al., 1992; Roether et al., 1996) and, in conjunction with the prevailing local sedimentary environmental conditions, are major drivers controlling the standing stocks and spatial distribution of benthic assemblages.

The eastern Mediterranean Sea is an extremely oligotrophic environment due to an increase in phosphorus limitation from west to east (Berman et al., 1984; Krom et al., 1991; Yacobi et al., 1995; Psarra et al., 2000), where low primary production rates coupled with high salinity, high temperatures and high oxygen content lead to increased organic matter channelling through the microbial food web (Siokou-Frangou et al., 2002). The northwestern Mediterranean Sea is a more productive area as it is affected by freshwater discharges from the Rhône, Ebro and other rivers, resulting in downslope transport of terrigenous material and input of organic matter into the bathyal benthos. Previous studies have reported primary and bacterial production rates to be 2-3 times lower in the eastern Mediterranean than in the west (Turley et al., 2000). This is also evident in the much higher fish production observed in the west (Caddy and Oliver, 1996).

Although the west to east productivity gradient applies as a general rule, there are specific features characterising certain areas within each sub-basin. For instance, areas such as the Gulf of Lion, the Adriatic Sea and the north Aegean Sea differ greatly from the rest of the main basin, displaying their own characteristics. The Gulf of Lion and the Adriatic Sea are directly influenced by the Rhône and Po River discharges respectively, and therefore represent more productive areas. Similarly, the north Aegean Sea, which belongs to the eastern Mediterranean and is perceived to be one of the most oligotrophic areas in the world, is none the less characterised by increased productivity as a result of the Black Sea inflow through the Dardanelles Strait (Poulos et al., 1997, 2000).

In the deep sea, the distribution and abundance of benthic communities is closely related to the quantity and quality of food input to the seafloor (Thiel, 1983; Tselepides and Eleftheriou, 1992; Pfannkuche et al., 1999; Danovaro et al., 2000a; Tselepides et $a l ., 2000$ c). In an extremely oligotrophic area such as the eastern Mediterranean Sea, meiofaunal abundance and biomass of deep sea sediments is generally low, decreasing sharply with increasing water depth (Danovaro et al., 1995, 2000a; Tselepides et al., 2000a). Benthic standing stocks have been found to be 2-25 times lower in the eastern part of the Mediterranean compared to the more productive northwestern part (de Bovée et al., 1990; Danovaro and Fabiano, 1995; Danovaro et al., 2000a). A notable exception are the Hellenic and Pliny trenches, which occasionally behave as benthic hot spots by accumulating organic matter and therefore supporting surprisingly high meiofaunal abundance (Tselepides and Lampadariou, 2004). Moreover, in a comparative study between the Gulf of LionCatalan Sea and the Cretan Sea, Danovaro et al. (1999) found bacterial densities to be four times higher and meiofaunal densities to be 4-25 times higher at bathyal depths in the western Mediterranean.

The present study deals with the distribution of meiobenthos from three bathyal basins of the Mediterranean Sea characterised by different productivity levels, namely the Balearic, the west Ionian and the east Ionian Seas. It also takes into account: (a) the spatial variability of the environmental parameters and (b) the changes in trophic conditions at three different depths $(600,800$ and $1500-1700 \mathrm{~m}$ ), as indicated by the organic content available to the meiobenthos.

\section{MATERIALS AND METHODS}

\section{Sampling strategy}

In the framework of the DESEAS research project (an exploratory survey to collect data of the exploited and virgin stocks of the deep-sea shrimp Aristeus antennatus), nine stations in the Mediterranean Sea were sampled at three sites along the continental slopes of the Balearic, the west Ionian and the east Ionian Sea. With the use of the R/V García del Cid three stations were sampled at depths ranging from 583 to $1735 \mathrm{~m}$ at each of the three sites (Fig. 1) in June-July 2001.

Undisturbed sediment samples were collected using a multiple corer of $10.4 \mathrm{~cm}$ internal diameter (i.d.). For the analysis of chloroplastic pigments, total organic carbon (TOC) and total organic nitrogen $(T O N)$, replicate $(n=3)$ cores from independent deployments of the multiple corer were sectioned 


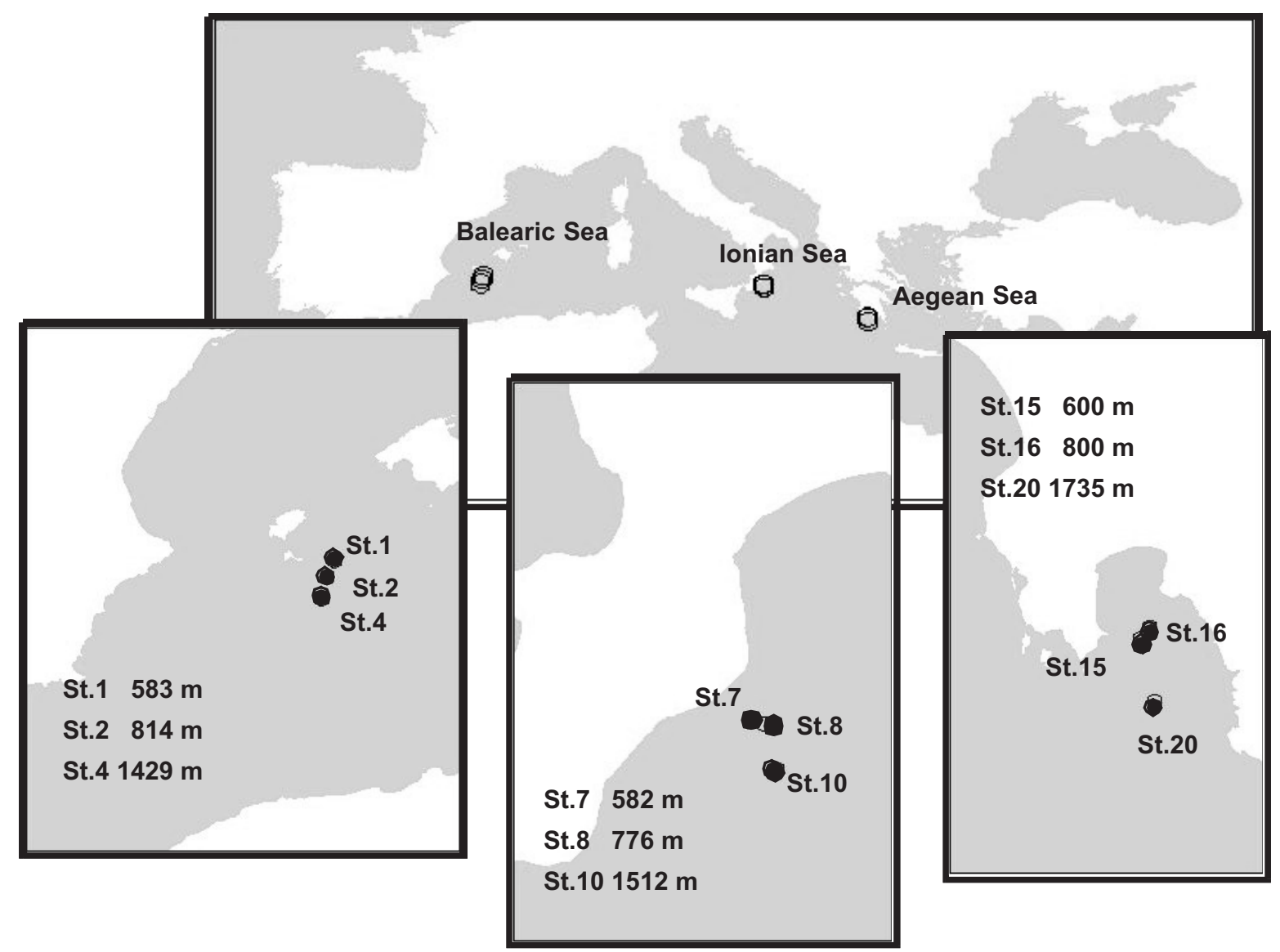

FIG. 1. - Map of the study areas and location of the sampling sites (St.).

into thin layers and stored at $-22^{\circ} \mathrm{C}$ for later laboratory analysis. For the grain size analysis, subsampling was carried out using Plexiglas tubes of $4.5 \mathrm{~cm}$ internal diameter.

For the analysis of meiobenthos, sediment subsamples were taken by inserting tubes of $4.5 \mathrm{~cm}$ i.d. in the larger multiple corer liners and sectioned into thin layers down to $5 \mathrm{~cm}$ depth. Immediately afterwards, samples were placed into a $\mathrm{MgCl}_{2}$ solution for 15 minutes for tissue relaxation and then fixed with a neutralised formaldehyde solution to a final concentration of $4 \%$.

\section{Analytical procedures}

Chlorophyll $a$ and phaeopigment concentrations were determined according to the fluorometric method of Yentsch and Menzel (1963) and Lorenzen and Jeffrey (1980). A TURNER 112 fluorometer was used with acetone (90\%) as an extractant (overnight in the dark), while phaeopigments were estimated by acidification with $0.1 \mathrm{~N} \mathrm{HCl}$. The fluorometer was calibrated using an acetone extract of pure chlorophyll $a$ from the algae Anacystis nidulans obtained from SIGMA. Chloroplastic pigment equivalents (CPE) were considered as the sum of chlorophyll $a$ and phaeopigment content.

Total organic carbon (TOC) and nitrogen (TON) concentrations were measured according to Hedges and Stern (1984), using a Perkin Elmer CHN 2400 analyser. Grain size analysis was performed according to the method described in Buchanan (1984).

\section{Meiobenthos analysis}

In the laboratory, meiobenthic samples were stained with Rose Bengal solution $\left(0.5 \mathrm{~g} \mathrm{l}^{-1}\right)$ and sieved through 500 and $32 \mu \mathrm{m}$ mesh size. The sediment containing the organisms retained on the 32 $\mu \mathrm{m}$ mesh was extracted by triplicate centrifugation in Ludox TM (density $1.15 \mathrm{~g} \mathrm{~cm}^{-3}$ ). All meiobenthic animals (Metazoa and soft shelled Foraminifera) in the supernatant and stained hard shelled Foraminifera remaining in the residual sediment were counted and identified to major taxa using a WILD stereomicroscope. 


\section{Data analysis}

For the various analyses, meiofauna data were retrieved from the upper $5 \mathrm{~cm}$ and sedimentary environmental variables from the upper $3 \mathrm{~mm}$.

The significance of differences between the investigated stations was tested by performing one way analysis of variance (ANOVA) after $\log (\mathrm{x}+1)$ transformations of the data using the STATISTICA v 5.1 module for Windows. Spearman's rank correlation coefficient was also used to test the correlations between meiofaunal and abiotic parameters.

Meiobenthic community data were classified using the Bray-Curtis Similarity Index (Bray and Curtis, 1957) and the group average linkage technique (Clarke and Warwick, 1994) based on square root transformations. Transformed biotic data were subjected to cluster analysis (Field et al., 1982) using the PRIMER package (Plymouth Marine Laboratory).

\section{RESULTS}

\section{Sedimentary parameters}

Table 1 gives a summary of all environmental parameters measured in the surface sediments in the Balearic and Ionian Seas. Stations 2 and 4 in the Balearic Sea and all stations in the west and east Ionian Sea were characterised by silty sediments (silt and clay $>87.3 \%$ ). Station 1 in the Balearic Sea was the only exception from the above pattern, being characterised by fine sand with a medium grain size of $0.097 \mathrm{~mm}$ and a silt-clay content of $74.52 \%$.

At the $600 \mathrm{~m}$ depth stations, concentrations of TOC and TON ranged from $0.39 \pm 0.01$ (west Ionian) to $0.60 \pm 0.06 \%$ (east Ionian) and from $0.05 \pm 0.01$ (west Ionian) to $0.09 \pm 0.01 \%$ (Balearic) respectively. The $\mathrm{C} / \mathrm{N}$ ratio was highest in the west Ionian Sea $(9.8$ \pm 0.2 ), decreasing to $6.0 \pm 1.1$ in the Balearic Sea. Concentrations of chlorophyll $a$ were lowest in the east Ionian $\left(0.12 \pm 0.04 \mu \mathrm{g} \mathrm{g}^{-1}\right)$ and highest in the Balearic Sea $\left(0.67 \pm 0.08 \mu \mathrm{g} \mathrm{g}^{-1}\right)$. Phaeopigments and CPE ranged from $0.53 \pm 0.06$ to $1.18 \pm 0.16$ and from $0.67 \pm 0.05$ to $1.29 \pm 0.23 \mu \mathrm{g} \mathrm{g}^{-1}$ respectively, with the lowest values being recorded in the west Ionian Sea and the highest in the Balearic Sea. Chlorophyll $a / \mathrm{CPE}$ ratio ranged from $0.15 \pm 0.01$ (east Ionian) to $0.22 \pm 0.04$ (west Ionian Sea).

At the $800 \mathrm{~m}$ depth stations, the concentration of TOC and TON ranged from $0.60 \pm 0.04$ (Balearic) to $0.91 \pm 0.07 \%$ (west Ionian) and from $0.10 \pm 0.03$ (west Ionian) to $0.08 \pm 0.01 \%$ (east Ionian) respectively. The $\mathrm{C} / \mathrm{N}$ ratio was highest in the east Ionian Sea $(11.0 \pm 0.3)$, decreasing to $7.9 \pm 0.2$ in the Balearic Sea. Chlorophyll $a$ and phaeopigments ranged respectively from $0.21 \pm 0.05$ to $1.19 \pm 0.31$ and from $0.96 \pm 0.35$ to $6.93 \pm 1.77 \mu \mathrm{g} \mathrm{g}^{-1}$, and CPE ranged from $1.17 \pm 0.39$ to $8.12 \pm 2.07 \mu \mathrm{g} \mathrm{g}^{-1}$, the lowest values recorded in the Balearic and the highest in the west Ionian Sea. Chlorophyll $a / \mathrm{CPE}$ ratio ranged from $0.15 \pm 0.01$ (west Ionian) to $0.19 \pm 0.01$ (east Ionian Sea).

At the deeper stations (1500-1700 m), TOC and TON ranged from $0.58 \pm 0.05$ (Balearic) to $0.90 \pm$ $0.08 \%$ (west Ionian) and from $0.08 \pm 0.01$ (Balearic) to $0.10 \pm 0.02 \%$ (west Ionian) respectively. The $\mathrm{C} / \mathrm{N}$ ratio was highest in the west Ionian Sea $(10.9 \pm 2.1)$, decreasing to $8.2 \pm 1$ in the Balearic Sea. Chloroplastic pigments were lowest in the east Ionian and highest in the west Ionian Sea, whereas chlorophyll $a$ and phaeopigments ranged from 0.13 \pm 0.02 to $0.81 \pm 0.17$ and from $0.66 \pm 0.10$ to $4.84 \pm$

TABLE 1. - Mean values and standard deviations (s.d.) of sedimentary parameters in the top $3 \mathrm{~mm}$ sediment layer of the sampling stations. TOC, organic carbon; TON, organic nitrogen; $\mathrm{C} / \mathrm{N}$, carbon to nitrogen ratio; Chl. $a$, clorophyll $a$; Phaeop., phaeopigments; CPE, chloroplastic pigment equivalent; Chl.a/CPE, ratio of Chl.a to CPE; MD, medium diameter of the sediment; \% S\&C, percentage of silt and clay.

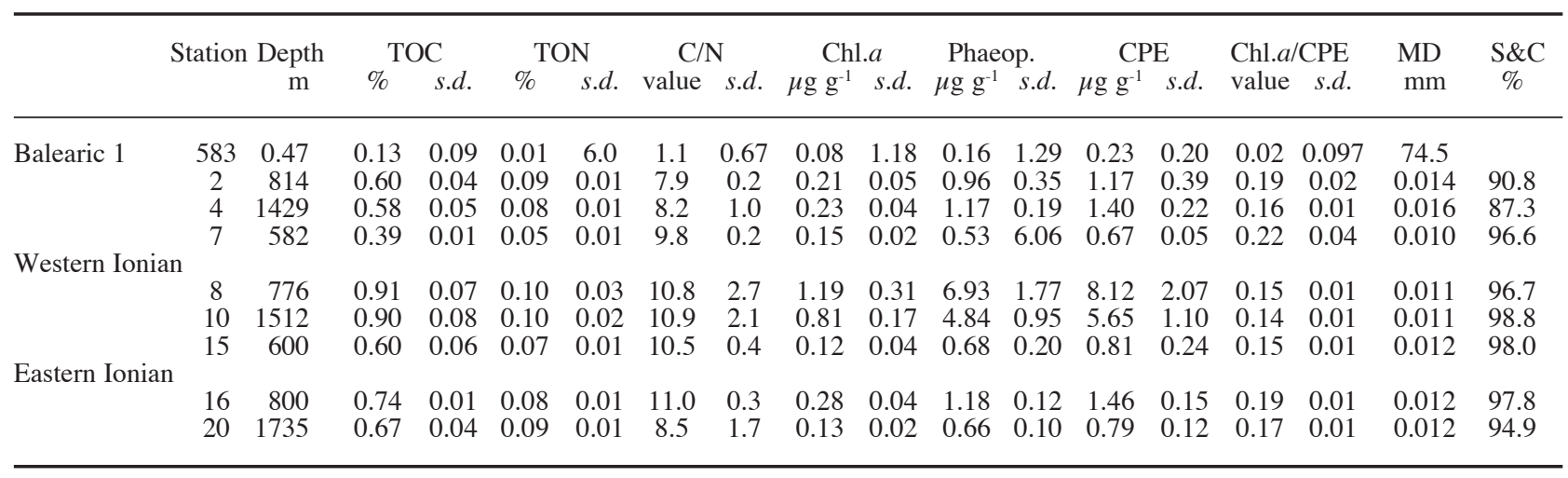




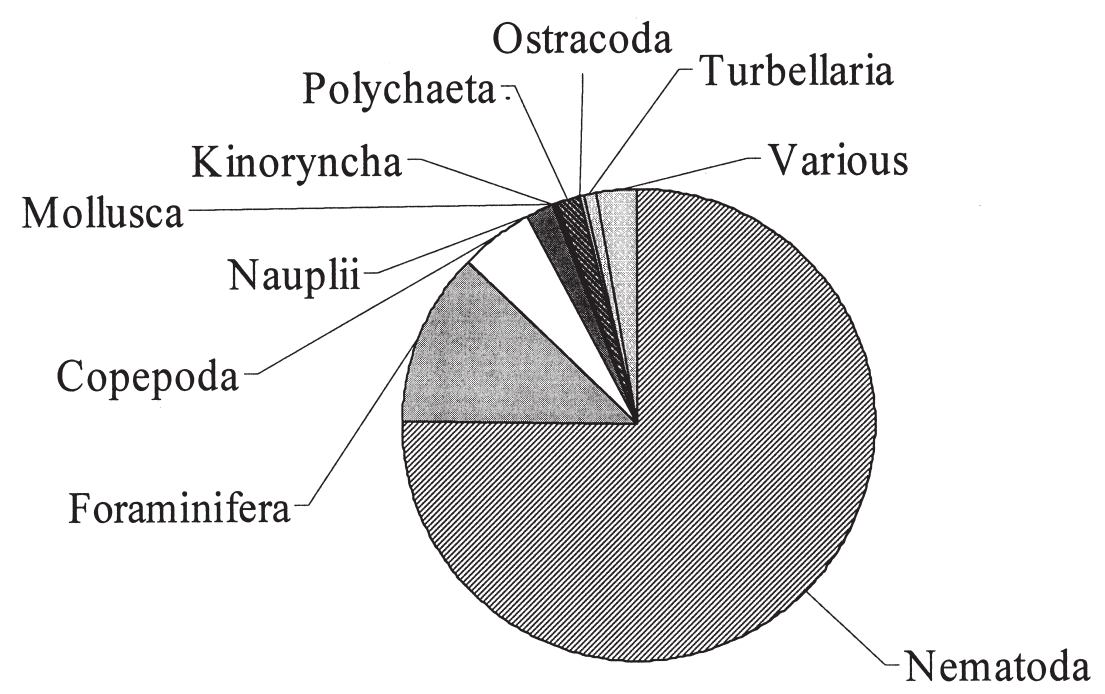

FIG. 2. - Average contribution (\%) of different groups to the total meiobenthos in the entire study area.

$0.95 \mu \mathrm{g} \mathrm{g}^{-1}$ respectively. CPE ranged from $0.79 \pm$ 0.12 to $5.65 \pm 1.10 \mu \mathrm{g} \mathrm{g}^{-1}$. Chlorophyll $a / \mathrm{CPE}$ ratio ranged from $0.14 \pm 0.01$ (west Ionian) to $0.17 \pm 0.01$ (east Ionian Sea).

\section{Distribution of meiobenthos}

Nematodes were the most abundant group (70$82 \%$ ), followed by Foraminifera (8-19\%), and harpacticoid copepods (adults and nauplii, 2-11\%). Polychaetes accounted for $1-3 \%$ of the total community, whereas the contribution of kinorynchs, gastrotrichs, turbellarians, nemertines, molluscs and other groups was $\leq 1 \%$ (Fig. 2 ).

The lowest density of total meiobenthos (both metazoans and foraminiferans) was recorded at station 20 in the east Ionian $\left(93 \pm 16\right.$ ind $\left..10 \mathrm{~cm}^{-2}\right)$ and the highest at station 8 in the west Ionian Sea (797 \pm 96 ind.10 $\mathrm{cm}^{-2}$ ). In the Balearic Sea, total meiobenthic density ranged from $197 \pm 64$ to 359 \pm 15 ind. $10 \mathrm{~cm}^{-2}$, whereas in the west and east Ionian Seas, meiobenthic density ranged from 220 \pm 56 to $797 \pm 96$ ind $.10 \mathrm{~cm}^{-2}$ and from $93 \pm 16$ to $218 \pm 18$ ind. $10 \mathrm{~cm}^{-2}$ respectively. Patterns of meiobenthos standing stock related to depth differed between the investigated areas. In the Balearic Sea, there was no significant difference in total abundance associated with changes in water depth (Fig. 3). In contrast, in the west Ionian Sea, abundance differed significantly among the sampling stations $(\mathrm{P}<0.001)$, being higher at $800 \mathrm{~m}$, whereas in the east Ionian Sea, abundance decreased significantly with increasing water depth $(\mathrm{P}<0.01)$ (Figs. 3-5).
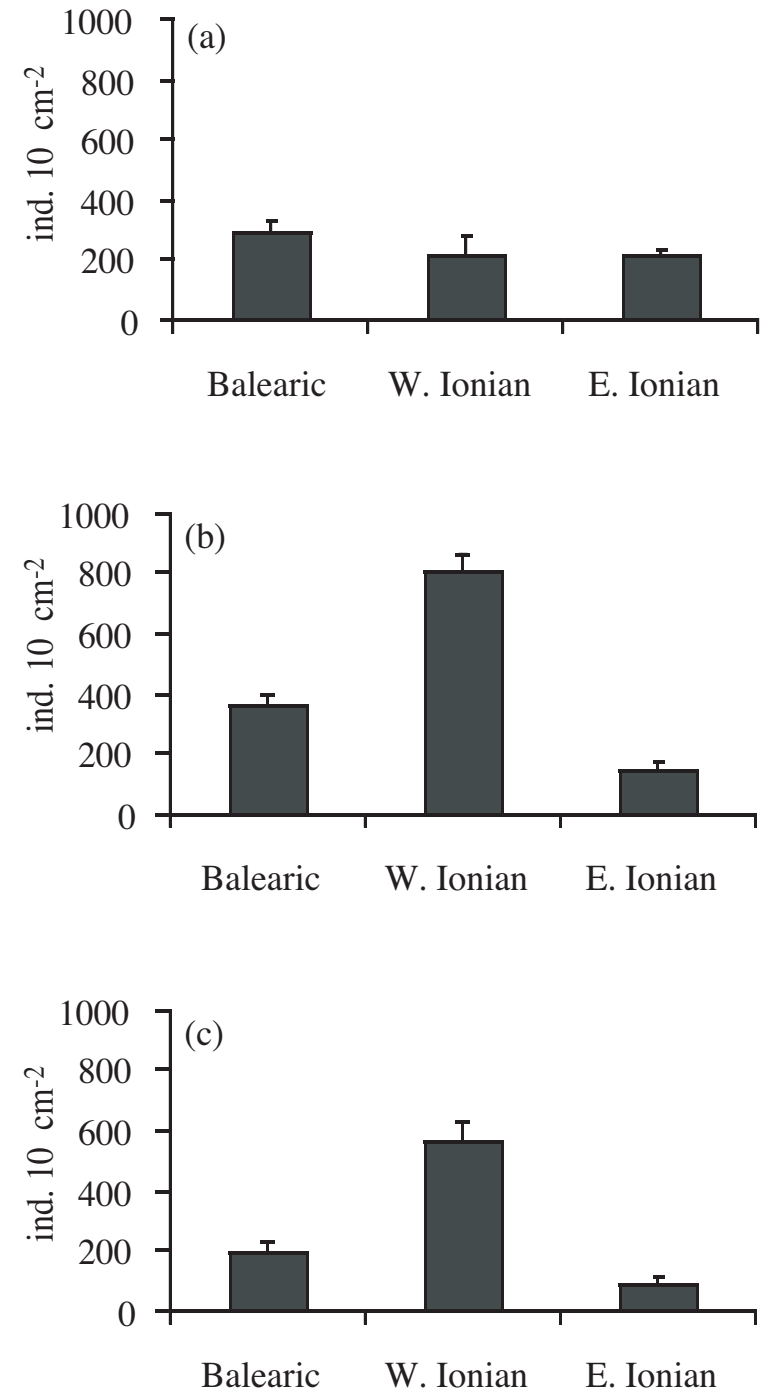

FIG. 3. - Total meiobenthic abundance in the upper $5 \mathrm{~cm}$ of the sediment. (a), Stations of $600 \mathrm{~m}$ depth (St. 1, 7, 15); (b), Stations of $800 \mathrm{~m}$ depth (St. 2, 8, 16); (c), Stations of 1500-1700 m depth (St. 4, 10, 20). 


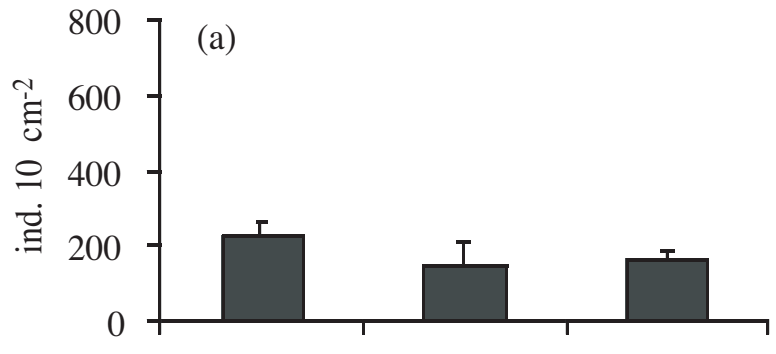

Balearic W. Ionian E. Ionian

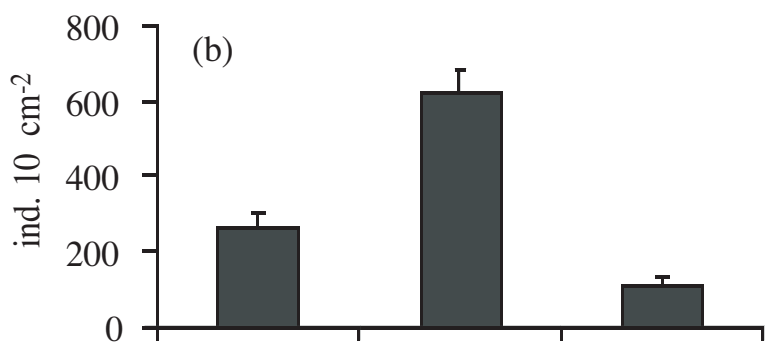

Balearic W. Ionian E. Ionian

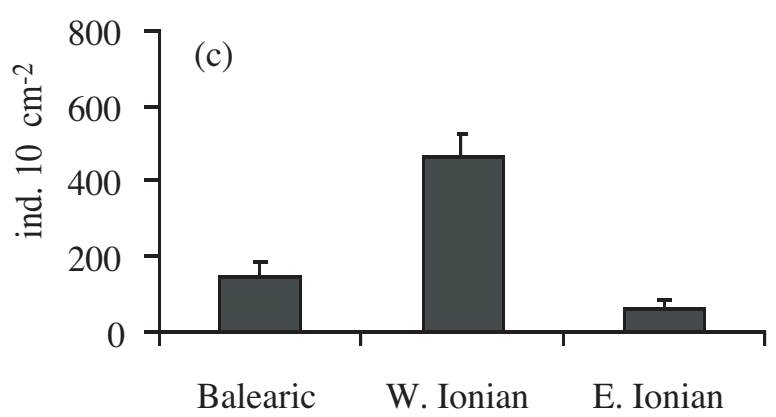

FIG. 4. - Nematode density in the upper $5 \mathrm{~cm}$ of the sediment. (a), Stations of $600 \mathrm{~m}$ depth (St. 1, 7, 15); (b), Stations of $800 \mathrm{~m}$ depth (St. 2, 8, 16); (c), Stations of 1500-1700 m depth (St. 4, 10, 20).

At the $600 \mathrm{~m}$ stations, while the different meiobenthic groups displayed different distributional patterns, no significant changes in abundance were found between the three sub-areas (Figs. 4, 5). Thus, nematode and copepod abundance ranged from $153 \pm 55$ to $229 \pm 21$ ind. $10 \mathrm{~cm}^{-2}$ and from $9 \pm$ 3 to $13 \pm 1$ ind. $10 \mathrm{~cm}^{-2}$ respectively, whereas Turbellaria ranged from $1 \pm 0.6$ (east Ionian) to $3 \pm$ 0.1 ind.10 $\mathrm{cm}^{-2}$ (Balearic Sea). On the other hand, Foraminifera and polychaetes displayed their highest abundances in the west Ionian Sea ( $37 \pm 5$ and 3 \pm 1 ind. $10 \mathrm{~cm}^{-2}$ respectively).

At the $800 \mathrm{~m}$ stations, nematodes, Foraminifera and copepods attained remarkably high densities in the west Ionian Sea (Fig. 4, 5), far above those measured at all other stations and sub-areas (ANOVA, $\mathrm{P}<$ 0.001). Thus, abundance of nematodes and Fora-

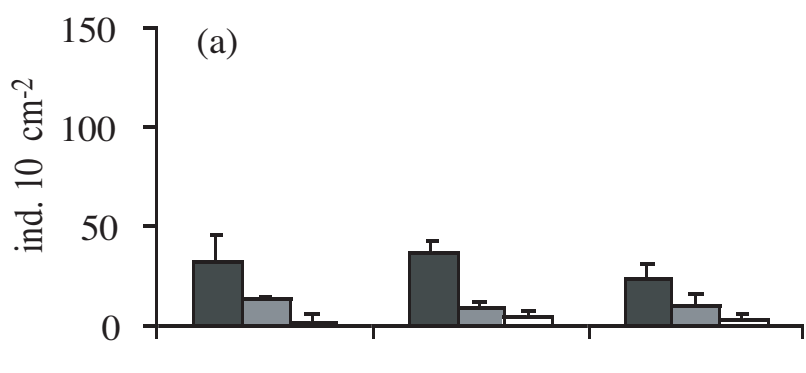

Balearic W. Ionian E. Ionian

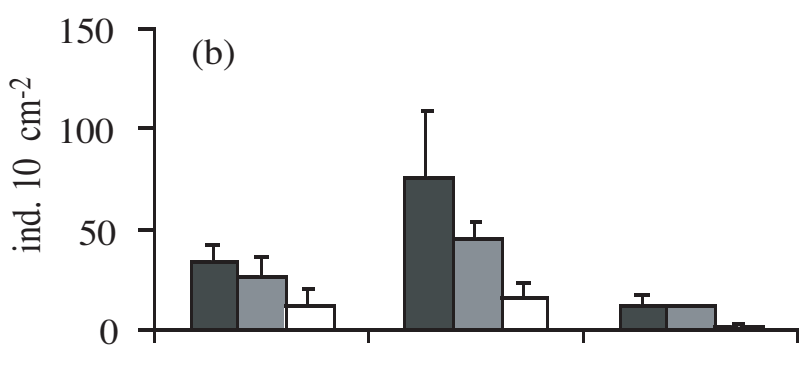

Balearic W. Ionian E. Ionian

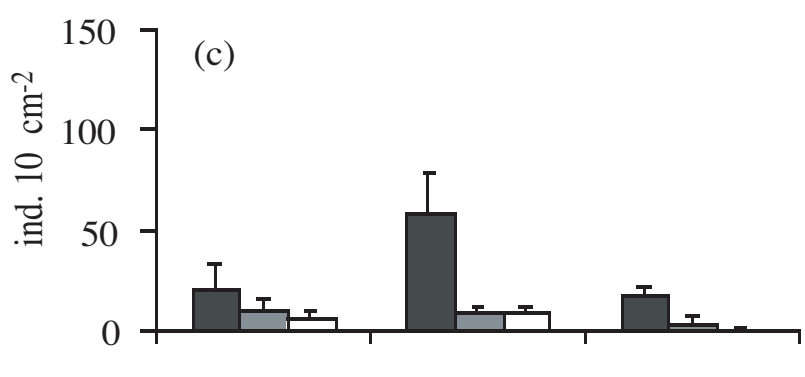

FIG. 5. - Abundance of foraminifers, adult copepods and copepod nauplii in the upper $5 \mathrm{~cm}$ of the sediment. (a) Stations of $600 \mathrm{~m}$ depth (St. 1, 7, 15); (b), Stations of $800 \mathrm{~m}$ depth (St. 2, 8, 16); (c), Stations of 1500-1700 m depth (St. 4, 10, 20). Black bars, foraminifers; gray bars, copepods; white bars, nauplii.

minifera varied from $113 \pm 41$ to $615 \pm 59$ and from $12 \pm 5$ to $76 \pm 33$ ind. $10 \mathrm{~cm}^{-2}$ respectively, whereas that of adult copepods ranged from $12 \pm 0.1$ to $45 \pm 9$ ind. $10 \mathrm{~cm}^{-2}$. This pattern of significantly high abundances of the most important meiobenthic groups in the western Ionian Sea was also evident at the 1500$1700 \mathrm{~m}$ stations (ANOVA, $\mathrm{P}<0.01$ ), with the exception of copepods, which attained their maximum abundance in the Balearic Sea (Fig. 5). At this depth range, the abundance of nematodes and Foraminifera varied from $66 \pm 110$ to $435 \pm 10$ and from $18 \pm 3$ to $57 \pm 21$ ind. $10 \mathrm{~cm}^{-2}$ respectively.

Cluster analysis using square-root transformed abundances clearly separated the west Ionian $800 \mathrm{~m}$ and $1500 \mathrm{~m}$ stations at the $70 \%$ cut-off point (Fig. 6). With the exception of the $1500 \mathrm{~m}$ stations from 


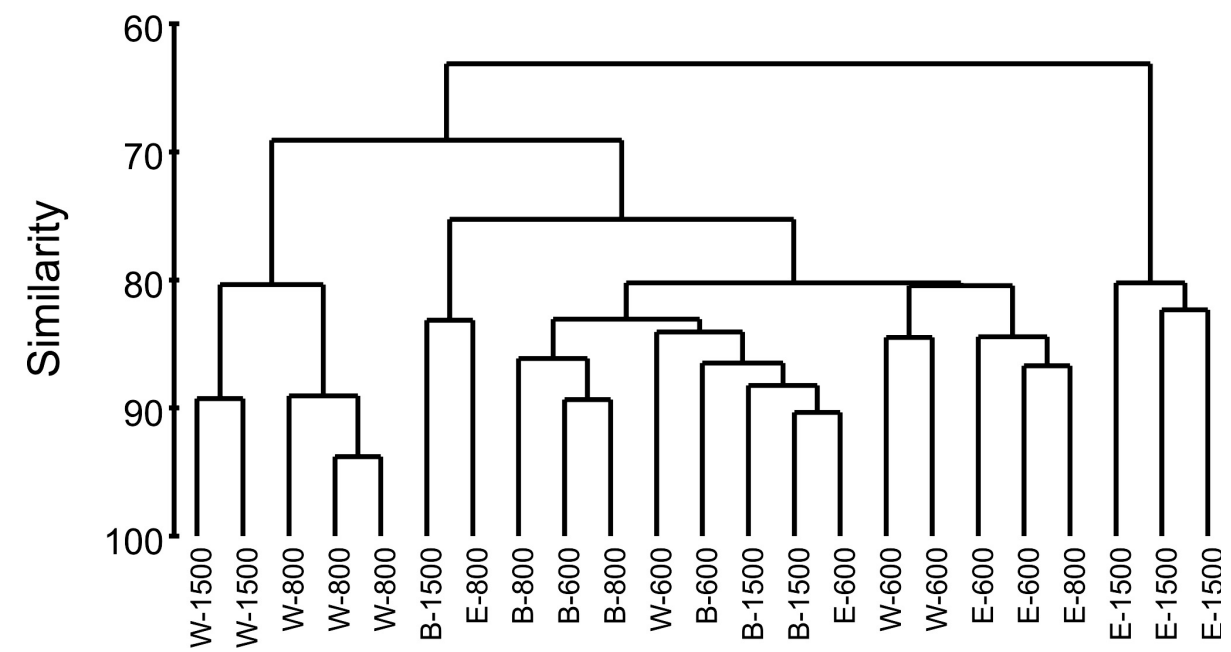

FIG. 6. - Bray-Curtis similarity dendrogram from square root transformed abundances. Letters refer to the sub-basins and numbers to station depth. B, Balearic; W, Western Ionian; E, Eastern Ionian.
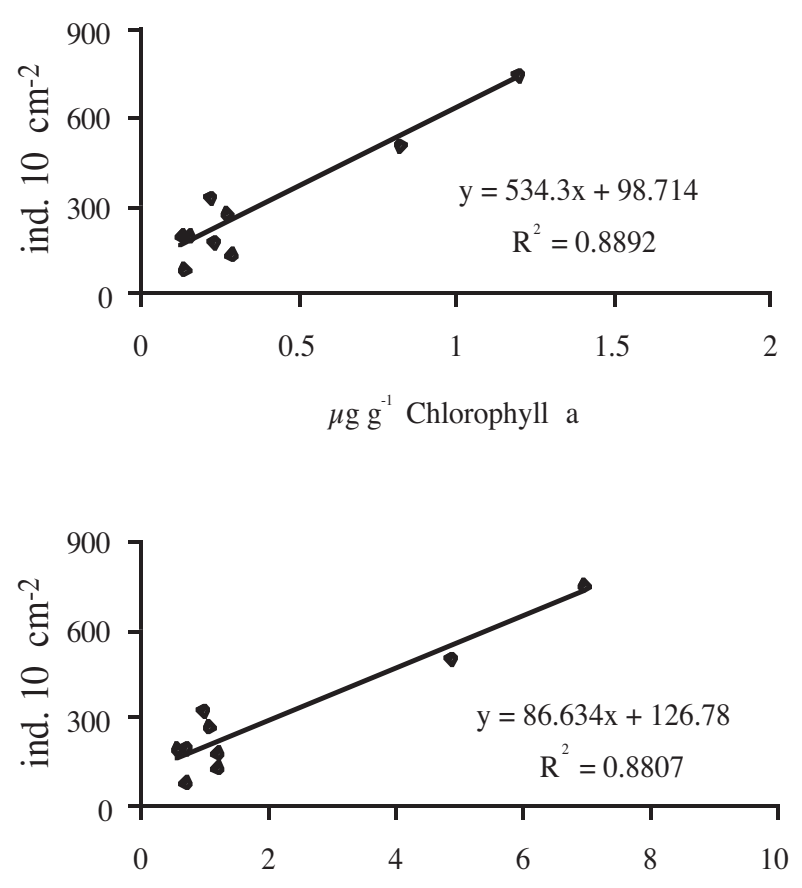

$\mu \mathrm{g} \mathrm{g}^{-1}$ Phaeopigments

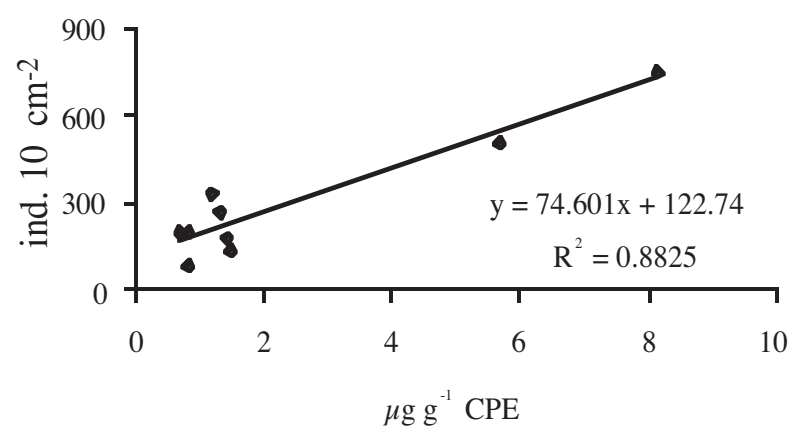

FIG. 7. - Linear regression plots of total meiobenthic abundances in the upper $5 \mathrm{~cm}$ of the sediment versus Chlorophyll $a$ Phaeopigments and CPE $(\mathrm{P}<0.001)$
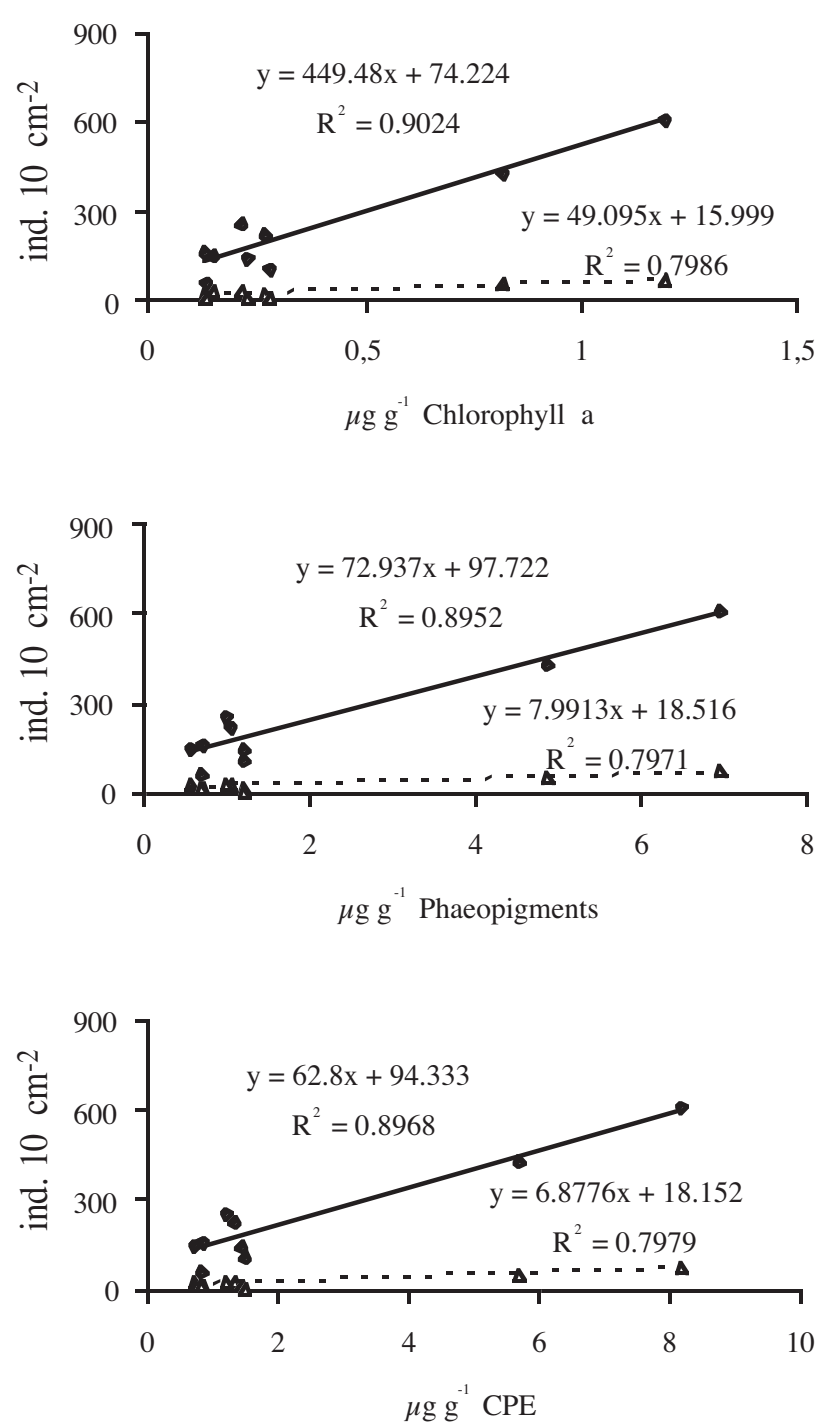

FIG. 8. - Linear regression plots of nematodes (continuous line, $\mathrm{P}<$ $0.001)$ and foraminiferan abundance (dashed line, $\mathrm{P}<0.01)$ in the upper $5 \mathrm{~cm}$ of the sediment versus Chlorophyll $a$, Phaeopigments and CPE. 
TABLE 2. - Spearman Correlation Coefficients between meiobenthic abundances and sedimentary parameters at the stations of $600 \mathrm{~m}$ depth ( $\mathrm{p} \leq$ 0.05). Nem., nematodes; Cop., copepods; nau., nauplii; Pol., polychaetes; Tur., Turbellaria; For., Foraminifera; Total, total meiobenthos; Chl.a, chlorophyll $a$; Phaeo., phaeopigments; CPE, chloroplastic pigment equivalent; Chl.a/CPE, ratio of Chl. $a$ to CPE; TOC, organic carbon; TON, organic nitrogen; $\mathrm{C} / \mathrm{N}$, carbon to nitrogen ratio; $\mathrm{MD}$, medium diameter of sediment; \% S\&C, percentage of silt and clay.

\begin{tabular}{|c|c|c|c|c|c|c|c|c|c|c|c|c|c|c|c|}
\hline & Nem. & Cop. & nau. & Pol. & Tur. & For. & Total & Chl. $a$ & Phaeo. & $\mathrm{CPE}$ & $\begin{array}{l}\text { Chl.al } \\
\text { CPE }\end{array}$ & TOC & TON & $\mathrm{C} / \mathrm{N}$ & $\mathrm{MD} \% \mathrm{~S} \& \mathrm{C}$ \\
\hline Nematodes & 1.000 & & & & & & & & & & & & & & \\
\hline Copepods & 0.434 & 1.000 & & & & & & & & & & & & & \\
\hline nauplii & -0.443 & -0.018 & 1.000 & & & & & & & & & & & & \\
\hline Polychaetes & -0.048 & -0.217 & -0.287 & 1.000 & & & & & & & & & & & \\
\hline Turbellaria & 0.147 & -0.068 & 0.000 & -0.773 & 1.000 & & & & & & & & & & \\
\hline Foraminifera & 0.048 & 0.048 & 0.383 & -0.810 & 0.761 & 1.000 & & & & & & & & & \\
\hline Total & 0.952 & 0.374 & -0.323 & -0.167 & 0.368 & 0.262 & 1.000 & & & & & & & & \\
\hline Chl. $a$ & 0.405 & -0.084 & -0.084 & -0.286 & 0.356 & -0.048 & 0.405 & 1.000 & & & & & & & \\
\hline Phaeo. & 0.714 & 0.060 & -0.335 & -0.071 & 0.454 & 0.000 & 0.786 & 0.738 & 1.000 & & & & & & \\
\hline CPE & 0.714 & 0.060 & -0.335 & -0.071 & 0.454 & 0.000 & 0.786 & 0.738 & 1.000 & 1.000 & & & & & \\
\hline Chl.a/CPE & -0.190 & -0.241 & -0.072 & -0.619 & 0.528 & 0.381 & -0.143 & 0.429 & -0.024 & -0.024 & 1.000 & & & & \\
\hline TOC & 0.119 & -0.096 & -0.263 & 0.881 & -0.565 & -0.810 & 0.048 & 0.095 & 0.310 & 0.310 & -0.548 & 1.000 & & & \\
\hline TON & 0.667 & 0.386 & -0.299 & 0.143 & 0.037 & -0.381 & 0.619 & 0.643 & 0.833 & 0.833 & -0.286 & 0.524 & 1.000 & & \\
\hline $\mathrm{C} / \mathrm{N}$ & -0.571 & -0.771 & -0.024 & 0.333 & -0.356 & -0.190 & -0.643 & -0.333 & -0.595 & -0.595 & 0.190 & -0.024 & -0.714 & 1.000 & \\
\hline MD & 0.580 & 0.453 & -0.279 & 0.013 & 0.065 & -0.353 & 0.504 & 0.567 & 0.718 & 0.718 & -0.290 & 0.353 & 0.945 & -0.718 & 1.000 \\
\hline$\% \mathrm{~S} \& \mathrm{C}$ & -0.421 & -0.261 & 0.127 & 0.819 & -0.766 & -0.554 & -0.504 & -0.643 & -0.491 & -0.491 & -0.693 & 0.554 & -0.265 & 0.491 & $-0.280 \quad 1.000$ \\
\hline
\end{tabular}

TABLE 3. - Spearman Correlation Coefficients between meiobenthic abundances and sedimentary parameters at the stations of $800 \mathrm{~m}$ depth ( $\mathrm{p} \leq$ 0.05). Nem., nematodes; Cop., copepods; nau., nauplii; Pol., polychaetes; Tur., Turbellaria; For., Foraminifera; Total, total meiobenthos; Chl. $a$, chlorophyll $a$; Phaeo., phaeopigments; CPE, chloroplastic pigment equivalent; Chl.a/CPE, ratio of Chl. $a$ to CPE; TOC, organic carbon; TON, organic nitrogen; $\mathrm{C} / \mathrm{N}$, carbon to nitrogen ratio; MD, medium diameter of sediment; $\% \mathrm{~S} \& \mathrm{C}$, percentage of silt and clay.

\begin{tabular}{|c|c|c|c|c|c|c|c|c|c|c|c|c|c|c|c|}
\hline & Nem. & Cop. & nau. & Pol. & Tur. & For. & Total & Chl. $a$ & Phaeo. & CPE & $\begin{array}{l}\text { Chl.al } \\
\text { CPE }\end{array}$ & TOC & TON & $\mathrm{C} / \mathrm{N}$ & $\mathrm{MD} \% \mathrm{~S} \& \mathrm{C}$ \\
\hline Nematodes & 1.000 & & & & & & & & & & & & & & \\
\hline Copepods & 0.883 & 1.000 & & & & & & & & & & & & & \\
\hline nauplii & 0.893 & 0.739 & 1.000 & & & & & & & & & & & & \\
\hline Polychaetes & 0.893 & 0.775 & 0.643 & 1.000 & & & & & & & & & & & \\
\hline Turbellaria & 0.541 & 0.500 & 0.360 & 0.378 & 1.000 & & & & & & & & & & \\
\hline Foraminifera & 0.964 & 0.847 & 0.964 & 0.786 & 0.468 & 1.000 & & & & & & & & & \\
\hline Total & 1.000 & 0.883 & 0.893 & 0.893 & 0.541 & 0.964 & 1.000 & & & & & & & & \\
\hline Chl. $a$ & 0.643 & 0.631 & 0.571 & 0.750 & -0.090 & 0.679 & 0.643 & 1.000 & & & & & & & \\
\hline Phaeo. & 0.750 & 0.613 & 0.750 & 0.750 & 0.108 & 0.821 & 0.750 & 0.929 & 1.000 & & & & & & \\
\hline $\mathrm{CPE}$ & 0.750 & 0.613 & 0.750 & 0.750 & 0.108 & 0.821 & 0.750 & 0.929 & 1.000 & 1.000 & & & & & \\
\hline Chl.a/CPE & -0.714 & -0.631 & -0.750 & -0.607 & -0.270 & -0.821 & -0.714 & -0.750 & -0.857 & -0.857 & 1.000 & & & & \\
\hline TOC & 0.714 & 0.595 & 0.536 & 0.893 & 0.072 & 0.679 & 0.714 & 0.929 & 0.893 & 0.893 & -0.714 & 1.000 & & & \\
\hline TON & 0.571 & 0.450 & 0.643 & 0.464 & -0.126 & 0.536 & 0.571 & 0.286 & 0.286 & 0.286 & -0.179 & 0.286 & 1.000 & & \\
\hline $\mathrm{C} / \mathrm{N}$ & -0.107 & -0.054 & -0.357 & 0.214 & 0.018 & -0.143 & -0.107 & 0.393 & 0.286 & 0.286 & -0.214 & 0.464 & -0.579 & 1.000 & \\
\hline MD & -0.543 & -0.648 & -0.472 & -0.794 & -0.086 & -0.643 & -0.643 & -0.945 & -0.869 & -0.869 & 0.794 & -0.945 & -0.113 & -0.567 & 1.000 \\
\hline$\% \mathrm{~S} \& \mathrm{C}$ & -0.378 & -0.381 & -0.472 & 0.000 & -0.620 & -0.378 & -0.378 & 0.378 & 0.189 & 0.189 & 0.000 & 0.378 & -0.378 & 0.756 & $-0.400 \quad 1.000$ \\
\hline
\end{tabular}

the eastern Ionian, which formed a third separate cluster, all other stations were grouped together.

The relationship between meiobenthos and food availability is shown in Figure 7. It should be mentioned here that the results from the regression analysis must be read with caution due to the low number of station points. Nevertheless, all correlations were highly significant, so the results shown in Figures 7 and 8 provide an indication of the relationship between meiofauna and food supply to the benthos. Total meiobenthic density increased with increasing food supply $(\mathrm{P}<0.001)$, expressed either as chlorophyll $a$, phaeopigments or CPE. Strong relationships were also found for the abundances of Nematodes $(\mathrm{P}<0.001)$ and Foraminifera $(\mathrm{P}<0.01)$ with chloroplastic pigments (Fig. 8). In contrast, adult copepods or copepod nauplii did not show any clear correlation with chlorophyll $a$, phaeopigments or CPE. The non-parametric correlation between the biological abundances and all the measured environmental variables are presented in Tables 2 to 4 . At the $600 \mathrm{~m}$ depth stations, only nematode abundance was correlated with phaeopigments and CPE, whereas abundance of polychaetes was correlated with TOC (Table 2). At the $800 \mathrm{~m}$ and 1500-1700 m depth stations, strong correlations were found between different faunal groups and phaeopigments or CPE. In particular, at the $800 \mathrm{~m}$ depth stations, total density as well as densities of nematodes, foraminiferans and copepod nauplii was closely cor- 
TABLE 4. - Spearman Correlation Coefficients between meiobenthic abundances and sedimentary parameters at the stations of $1500-1700 \mathrm{~m}$ depth (P $\leq$ 0.05). Nem., nematodes; Cop., copepods; nau., nauplii; Pol., polychaetes; Tur., Turbellaria; For., Foraminifera; Total, total meiobenthos; Chl.a, chlorophyll $a$; Phaeo., phaeopigments; CPE, chloroplastic pigment equivalent; Chl.a/CPE, ratio of Chl.a to CPE; TOC, organic carbon; TON, organic nitrogen; C/N, carbon to nitrogen ratio; MD, medium diameter of sediment; $\%$ S\&C, percentage of silt and clay.

\begin{tabular}{|c|c|c|c|c|c|c|c|c|c|c|c|c|c|c|c|}
\hline & Nem. & Cop. & nau. & Pol. & Tur. & For. & Total & Chl.a & Phaeo. & CPE & $\begin{array}{l}\text { Chl.al } \\
\text { CPE }\end{array}$ & TOC & TON & $\mathrm{C} / \mathrm{N}$ & $\mathrm{MD} \% \mathrm{~S} \& \mathrm{C}$ \\
\hline Nematodes & 1.000 & & & & & & & & & & & & & & \\
\hline Copepods & 0.663 & 1.000 & & & & & & & & & & & & & \\
\hline nauplii & 0.838 & 0.855 & 1.000 & & & & & & & & & & & & \\
\hline Polychaetes & 0.790 & 0.370 & 0.753 & 1.000 & & & & & & & & & & & \\
\hline Turbellaria & 0.897 & 0.558 & 0.805 & 0.781 & 1.000 & & & & & & & & & & \\
\hline Foraminifera & 0.850 & 0.497 & 0.723 & 0.741 & 0.896 & 1.000 & & & & & & & & & \\
\hline Total & 0.976 & 0.783 & 0.886 & 0.755 & 0.861 & 0.850 & 1.000 & & & & & & & & \\
\hline Chl.a & 0.929 & 0.663 & 0.743 & 0.683 & 0.764 & 0.635 & 0.905 & 1.000 & & & & & & & \\
\hline Phaeo. & 0.905 & 0.783 & 0.790 & 0.647 & 0.727 & 0.635 & 0.929 & 0.976 & 1.000 & & & & & & \\
\hline CPE & 0.905 & 0.783 & 0.790 & 0.647 & 0.727 & 0.635 & 0.929 & 0.976 & 1.000 & 1.000 & & & & & \\
\hline Chl.a/CPE & -0.476 & -0.578 & -0.611 & -0.635 & -0.436 & -0.491 & -0.595 & -0.500 & -0.619 & -0.619 & 1.000 & & & & \\
\hline TOC & 0.262 & -0.024 & 0.060 & 0.311 & 0.436 & 0.395 & 0.238 & 0.333 & 0.310 & 0.310 & -0.476 & 1.000 & & & \\
\hline TON & -0.214 & -0.602 & -0.599 & -0.096 & -0.412 & -0.299 & -0.286 & -0.048 & -0.119 & -0.119 & 0.071 & 0.238 & 1.000 & & \\
\hline $\mathrm{C} / \mathrm{N}$ & 0.548 & 0.639 & 0.647 & 0.467 & 0.740 & 0.635 & 0.619 & 0.524 & 0.595 & 0.595 & -0.690 & 0.667 & -0.476 & 1.000 & \\
\hline $\mathrm{MD}$ & -0.265 & 0.006 & -0.127 & -0.380 & -0.423 & -0.494 & -0.265 & -0.265 & -0.265 & -0.265 & 0.567 & -0.945 & -0.189 & -0.643 & 1.000 \\
\hline$\% \mathrm{~S} \& \mathrm{C}$ & 0.265 & -0.006 & 0.127 & 0.380 & 0.423 & 0.494 & 0.265 & 0.265 & 0.265 & 0.265 & -0.567 & 0.945 & 0.189 & 0.643 & $-1.000 \quad 1.000$ \\
\hline
\end{tabular}

related with phaeopigments and CPE (Table 3). At the deeper stations, total density as well as nematode and copepod density were closely correlated with chloroplastic pigments.

\section{DISCUSSION}

The available information on the distribution of meiobenthos in the bathyal zone of the Mediterranean Sea originates mainly from studies conducted in the Aegean, Cretan and Adriatic Seas (Danovaro et al., 1995, 2000a; Lampadariou, 2001) as well as from the Gulf of Lion (de Bovée et al., 1990; Soetaert et al., 1991; Danovaro et al., 1999) and Corsica (Soetaert et al., 1991). In the present study, quantitative information was obtained on the distribution of meiobenthos (both Metazoa and Foraminifera) from less investigated areas of the Mediterranean, such as the Balearic, as well as the west and the east Ionian Seas. These areas are of primary importance as they have the potential to be important fishing grounds for the Mediterranean red shrimp (Aristeus antennatus and Aristaeomorpha foliacea, Sardà et al., 2004).

Levels of meiofaunal abundance found during this study in the Balearic basin were lower than those of previous studies conducted in the western Mediterranean Sea. In the Gulf of Lion, Danovaro et al. (1999) reported metazoan densities of 703-1050 ind. $10 \mathrm{~cm}^{-2}$ at $600-800 \mathrm{~m}$, decreasing to $693-837$ ind. $10 \mathrm{~cm}^{-2}$ at $950-1300 \mathrm{~m}$. In the same area, de Bovée et al. (1990) found higher metazoan densities at the upper slope (556 ind. $10 \mathrm{~cm}^{-2}$ at $600 \mathrm{~m} \mathrm{depth}$ ), decreasing to $57-103$ ind. $10 \mathrm{~cm}^{-2}$ at $1700-1800 \mathrm{~m}$ depth. There are no data available from other studies on the meiobenthos in the Balearic Sea, apart from some data reported in Danovaro et al. (1999) from the EUROMARGE-NB project, which again reported metazoan densities of 783 ind. $10 \mathrm{~cm}^{-2}$ at $600-800$ $m$ depth, decreasing to 409 ind. $10 \mathrm{~cm}^{-2}$ at $950-1300$ $\mathrm{m}$.

In the Ionian Sea, the only available data so far on the distribution of meiobenthos at bathyal sites stems from the previous work of Danovaro et al. (1995), who at $600 \mathrm{~m}$ depth reported metazoan densities of 290 ind. $10 \mathrm{~cm}^{-2}$, decreasing significantly with depth (down to 4 ind. $10 \mathrm{~cm}^{-2}$ at $1700-1800 \mathrm{~m}$ ). In contrast to the lack of information regarding the Balearic and western Ionian, there is relatively more information available on the meiofaunal standing stock for the eastern Mediterranean, originating mainly from the Aegean Sea. The values reported here are similar to those found by Danovaro et al. (2000a) in the bathyal sediments of the Cretan Sea, and similar to those reported from other abyssal environments (Pfannkuche, 1985; Tietjen et al., 1989; Lambshead et al., 1995). Similarly, Lampadariou (2001), studying the meiobenthos of the eastern Mediterranean, found low and comparable metazoan densities in the Cretan Sea (128-346 ind. $10 \mathrm{~cm}^{-2}$ ) in contrast to the much higher values (839-1251 ind. $10 \mathrm{~cm}^{-2}$ ) found in the more productive north Aegean Sea, thus supporting the hypothesis that meiofaunal standing stocks in the eastern Mediterranean are closely related to food availabili- 
ty. The surprisingly high densities (435 ind. $10 \mathrm{~cm}^{-2}$ ) found in the abyssal sediments of the Hellenic and Pliny Trenches by Tselepides and Lampadariou (2004) give further support to this contention.

Regarding the foraminiferan communities, the available information and the studies conducted so far on the bathyal sediments of the Mediterranean Sea are very sparse. Furthermore, Foraminifera have (in past studies) been frequently neglected, even though they account for a major part of the meiobenthic abundance and biomass (Thiel, 1983; Gooday, 1986, 1992). Foraminiferal densities from this study, as well as from other studies in the Mediterranean, are much lower than those found in other areas of the world such as the Atlantic, the Pacific Ocean and the Arabian Sea (Reisig, 1982; Gooday and Turley, 1990; Gooday et al., 1996, 2000). This can be attributed to food availability (quantity and quality of detritus reaching the benthos) since Protozoa, like Metazoa, usually correlate very well with CPE and other phytopigments. Due to their short generation time and opportunistic feeding habits, small benthic organisms such as Protozoa are very well adapted to responding quickly to the variable food input to the deep-sea (Altenbach, 1992; Linke, 1992; Pfannkuche, 1993), whereas Metazoa fail to exploit and utilise phytodetritus as rapidly as Protozoa (Gooday et al., 1996).

It has been well documented that food availability is one of the most important factors controlling the distribution of benthic communities (Rowe, 1971; Smith et al., 1983; Lampitt, 1985; Graf, 1989). Indeed, faunal abundance and biomass are closely controlled by the quantity and quality of organic matter, and are strongly correlated with sedimentary chloroplastic pigments (since they reflect the bio-available fraction of the sedimentary organic matter) rather than organic carbon alone (Pfannkuche, 1985; Soetaert et al., 1991, 1997; Danovaro et al., 2000b). In our study, strong relationships were found between total meiobenthic density and chlorophyll $a$, phaeopigments and CPE. In fact, the distribution of densities among the investigated stations follows the distribution of the chloroplastic pigments within the sediment, although the various meiobenthic groups responded differently to the amount of food supply to the benthos. Thus, at the $600 \mathrm{~m}$ stations, significant correlations were found between nematodes, total meiobenthic density and the chloroplastic pigments of the sediment, expressed either as phaeopigments or CPE. In deeper areas, where food supply is more important and might become a limiting factor for benthic organisms, all meiofaunal taxa displayed a significant correlation with phaeopigments and CPE, whilst some groups such as nematodes, polychaetes and turbelarians displayed strong correlations with the amount of chlorophyll $a$. Correlations between the other measured environmental factors and the various meiobenthic taxa were also found but were scarce and displayed no clear pattern. This, once again, supports the contention that in the deep sea, input of food to the benthos is the main factor controlling the distribution of meiobenthos.

In the deep sea, there is a negative correlation between meiobenthic abundance and depth (Thiel, 1983; Tietjen, 1992), which is related to the decreasing supply of organic matter to the deep-sea floor. This general rule also applies to our study, although there were some marked exceptions, such as the high abundances observed below the $800 \mathrm{~m}$ isobath in the western Ionian. This clearly shows that other characteristics besides depth change, such as the specific hydrography of the different sub-basins, may also play an important role in structuring the meiobenthic communities. Physical forcing may affect the specific hydrographic mesoscale features of a certain area and therefore influence nutrient availability to the euphotic zone, primary productivity and eventually total organic matter flux to the benthos. Physical forcing may also directly affect the organic loading of sediments through processes such as convection and advection of specific water masses along isopycnals.

In the western sub-basin, the coastal area and the areas of river outlets have an increased fertilisation potential, representing a different ecosystem compared to the lower slope, the basin and the offshore pelagic areas: the Gulf of Lion, the Catalan shelf and the upper slope are directly influenced by landderived inputs caused by both anthropogenic and natural activities, and by nutrient discharges coming from the Rhône and other smaller rivers, displaying high productivity (Estrada, 1996; Moutin et al., 1998). On the other hand, the southern part at the Balearic Islands far from the impact of the Rhône river is a more oligotrophic area, mostly influenced by the Liguro-Provençal Current which is poor in nutrients and exhibits a deep nitracline and low primary production rates (Lefevre et al., 1997). This is supported by the study of Bianchi et al. (1999), who found the nitrification rates during spring to be considerably higher near the Rhône river plume area due to the riverine nitrogen inputs, compared to the 
southern stations which are located away from the river and as such are oligotrophic (Balearic islands). In a similar way, by studying the distribution of terrigenous and biogenic elements of suspended particulate matter in the Mediterranean Sea, Price et al. (1999) found very low concentrations of particulate $\mathrm{Al}$ and $\mathrm{Mn}$ in the sediments of the Balearic Sea compared to the high values recorded in the area off Banuls-sur-mer, implying a strong riverine influence in the latter.

The Ionian Sea is also known to be a very oligotrophic area of the Mediterranean Sea (Souvermezoglou et al., 1992; Rabitti et al., 1994; Napolitano et al., 2000). Boldrin et al. (2002) have measured low concentrations of suspended matter, coupled with low particle fluxes. However, wellestablished water mass circulation patterns can undergo transformations at a regional scale, thus complicating or changing the expected nutrient availability and therefore influencing phytoplankton and bacterial standing stocks and particulate organic matter fluxes. A northward flow in the central Ionian has replaced the strong southward current that was part of the Atlantic Ionian Stream. This modification seems to be related to the reversal of the anticyclonic circulation in the central Ionian (Theocharis et al., 2002). This, in conjunction with the wellknown transition in the source of dense water which took place during the early 1990s (Theocharis et al., 1999; Klein et al., 1999; Tselepides et al., 2000b), as the denser Aegean Sea waters replaced the Adriatic deep waters in the bottom layer of the northern Ionian basin, may well have affected the overall productivity in the area (Danovaro et al., 2001). On the western Ionian slope, a core of cold Adriatic, less saline deep water flows towards the south in a transitional level between the deep Aegean waters and the Levantine Intermediate Waters, at a depth of 800-1500 m (Manca et al., 2002), and as a result, either nutrient-rich deep waters are up-lifted into the euphotic zone thus impacting the productivity of the system or the richer in organic matter water of Adriatic origin directly affects the sedimentary environment and hence meiofaunal density.

In the present study, meiobenthic abundance at $600 \mathrm{~m}$ depth in the west and east Ionian Sea was low, indicative of the oligotrophic environment of the eastern Mediterranean Sea. This finding was also supported by the observed low concentrations of organic matter. On the other hand, the station at 800-1500 m depth were characterised by high meiofaunal densities which were also (as described above) strongly related to the higher concentrations of chloroplastic pigments deposited at this depth.

\section{ACKNOWLEDGEMENTS}

The authors would like to thank Dr. Francisco Sardà for the coordination of the cruise and the captain and the crew of the R/V García del Cid for their help during field operations and sampling. The authors would also like to thank D. Podaras, W. Plaiti, F. Pantazoglou and S. Tsolisos for assistance during the field work. This work was financially supported by the EU in the framework of the programme DESEAS: "Exploratory survey to collect data of the exploited and virgin stocks of deep sea shrimp A. antennatus, of interest to the CFP (Study Contract 2003/39)".

\section{REFERENCES}

Altenbach, A.V. - 1992. Short term processes and patterns in the foraminiferal response to organic flux rates. Mar. Micropaleontol.,19: 119-129.

Berman, T., D.W. Townsand, S.Z. El-Sayed, C.C. Trees and Y. Azov. - 1984. Optical transparency, chlorophyll and primary productivity in the Eastern Mediterranean near the Israeli coast. Oceanol. Acta, 7: 367-372.

Bethoux, J.P., P. Morin, C. Madec and B. Gentili. - 1992. Phosphorus and nitrogen behaviour in the Mediterranean Sea. Deep-Sea Res., 39: 1641-1654.

Bianchi, M., C. Fosset and P. Conan. - 1999. Nitrification rates in the NW Mediterranean Sea. Aquat. Microb. Ecol., 17: 267-278.

Boldrin, A., S. Miserocchi, S. Rabitti, M.M. Turchetto, V. Balboni and G. Socal. - 2002. Particulate matter in the southern Adriatic and Ionian Sea: characterisation and downward fluxes. J. Mar. Syst., 33-34: 389-410.

Bray, R.J. and J.T. Curtis. - 1957. An ordination of the upland forest communities of southern Winsconin. Ecol. Monogr., 27: 325-349.

Buchanan, J.B. - 1984. Sediment analysis. In: N.A. Holme, and A.D. McIntyre (eds.), Methods for the study of Marine Benthos., pp. 41-65. Blackwell Scientific Publications, Oxford.

Caddy, J.F. and P. Oliver. - 1996. Some future perspectives for assessment and management of Mediterranean fisheries for demersal and shellfish resources, and small pelagic fish. In: J.F. Caddy (ed.), Studies and Reviews. General Fisheries Council for the Mediterranean, pp. 19-60. FAO, Rome.

Clarke, K.R. and R.M. Warwick. - 1994. Similarity-based testing for community pattern: the two-way layout with no replication. Mar. Biol., 118: 167-176.

Crispi, G., R. Mosetti, C. Solidoro and A. Crise. - 2001. Nutrients cycling in Mediterranean basins: the role of the biological pump in the trophic regime. Ecol. Model., 138: 101-114.

Danovaro, R., N. Della Croce, A. Eleftheriou, M. Fabiano, N. Papadopoulou, C. Smith and A. Tselepides. - 1995. Meiofauna of the deep Eastern Mediterranean Sea: distribution, and abundance in relation to bacterial biomass, organic matter composition and other environmental factors. Prog. Oceanogr., 36: 329-341.

Danovaro, R. and M. Fabiano. - 1995. Meiofaunal abundance and distribution in bathyal sediments of the Mediterranean Sea: An overview. Biol. Mar. Medit., 2: 217-225.

Danovaro, R., A. Dinet, G. Duineveld and A. Tselepides. - 1999. Benthic response to particulate fluxes in different trophic environments: a comparison between the Gulf of Lions-Catalan Sea 
(western Mediterranean) and the Cretan Sea (eastern Mediterranean). Prog. Oceanog., 44: 287-312.

Danovaro, R., A. Tselepides, A. Otegui and N. Della Croce. 2000a. Dynamics of meiofaunal assemblages on the continental shelf and deep-sea sediments of the Cretan Sea (NE Mediterranean): relationships with seasonal changes in food supply. Prog. Oceanogr., 46: 367-400.

Danovaro, R., N. Della Croce, A. Dell'Anno, M. Fabiano, D. Marrale and D. Martorano. - 2000b. Seasonal changes and biochemical composition of labile organic matter flux in the Cretan Sea. Prog. Oceanog., 46: 259-278.

Danovaro, R., A. Dell' Anno, M. Fabiano, A. Pusceddu and A. Tselepides. - 2001. Deep-sea ecosystem response to climate changes: the eastern Mediterranean case study. Trends Ecol. Evol., 16: 505-510.

De Bovée, F., L.D. Guidi and J. Soyer. - 1990. Quantitative distribution of deep-sea meiobenthos in the northwestern Mediterranean (Gulf of Lions). Cont. Shelf Res., 10: 1123-1145.

Estrada, M. - 1996. Primary production in the northwestern Mediterranean. Sci. Mar., 60: 55-64.

Field, J.G., K.R. Clarke and R.M. Warwick. - 1982. A practical strategy for analysing multispecies distribution patterns. Mar. Ecol. Prog. Ser., 8: 37-52.

Gooday, A.J. - 1986. Meiofaunal foraminiferans from the bathyal Porcupine Seabight: size structure, taxonomic composition, species diversity and vertical distribution in the sediment. Deep-Sea Res., 33: 1345-1372.

Gooday, A.J. and C.M. Turley. - 1990. Responses by benthic organisms to input of organic material to the ocean floor: a review. Phil. Trans. Royal Soc. London, Series A 331: 119-138.

Gooday, A.J., L.A. Levin, P. Linke and T. Heeger. - 1992. The role of benthic foraminifera in deep-sea food webs and carbon cycling. In: G.T. Rowe and V. Pariente (eds.), Deep-Sea food chains and the global carbon cycle, pp. 63-91. Kluwer Academic Publishers.

Gooday, A.J., O. Pfannkuche and P.J.D. Lambshead. - 1996. An apparent lack of response by metazoan meiofauna to phytodetritus deposition to the bathyal north-eastern Atlantic. J. Mar. Biol. Ass. UK, 76: 297-310.

Gooday, A.J., J.M. Bernhard, L.A. Levin and S.B. Suhr. - 2000. Foraminifera in the Arabian Sea oxygen minimum zone and other oxygen-deficient settings: taxonomic composition, diversity, and relation to metazoan faunas. Deep-Sea Res., 47: 25-54.

Graf, G. - 1989. Benthic-pelagic coupling in a deep-sea benthic community. Nature, 341: 437-439.

Hedges, J.I. and J.H. Stern. - 1984. Carbon and nitrogen determination of carbonate-containing solids. Limnol. Oceanogr., 29: 657-663.

Klein, B., W. Roether, B. Manca, D. Bregant, V. Beitzel, V. Kovacevic and A. Luchetta. - 1999. The large deep water transient in the Eastern Mediterranean. Deep-Sea Res., 46: 371414.

Krom, M.D., N. Kress, S. Brenner and L.I. Gordon. - 1991. Phosphorus limitation of primary productivity in the eastern Mediterranean Sea. Limnol. Oceanogr., 36: 424-432.

Lambshead, P.J.D., T.J. Ferrero and G.A. Wolff. - 1995. Comparison of the vertical distribution of nematodes from two contrasting abyssal sites in the northeast Atlantic subject to different seasonal inputs of phytodetritus. Int. Revue Ges. Hydrobiol., 80: 327-332.

Lampadariou, N. - 2001. Study of the meiobenthic ecosystem of the Aegean Sea with a special emphasis on nematodes. Ph.D. thesis, University of Crete, Heraklion.

Lampitt, R.S. - 1985. Evidence for the seasonal deposition of detritus to the deep-sea floor and its subsequent resuspension. DeepSea Res., 32: 885-897.

Lefevre, D., H.J. Minas, M. Minas, C. Robinson, P.J. Le B. Williams and M.S. Woodward. - 1997. Review of gross community production, primary production, net community production and dark community respiration in the Gulf of Lions. Deep-Sea Res., 44: 801-832.

Linke, P. - 1992. Metabolic adaptations of deep-sea benthic foraminifera to seasonally varying food input. Mar. Ecol. Prog. Ser., 81: 51-63.

Lorenzen, C. and J. Jeffrey. - 1980. Determination of chlorophyll in sea water. UNESCO.

Manca, B.B., Kovacevic, V., Gacic, M. and D. Viezzoli - 2002. Dense water formation in the Southern Adriatic Sea and spread- ing into the Ionian Sea in the period 1997-1999. J. Mar. Syst., 33-34: 133-154.

Moutin, T., P. Raimbault, H.L. Golterman and B. Coste. - 1998 The input of nutrients by the Rhone river into the Mediterranean Sea: recent observations and comparison with earlier data. Hydrobiologia, 373/374: 237-246.

Napolitano, E., T. Oguz, P. Malanotte-Rizzoli, A. Yilmaz and E. Sansone. - 2000. Simulations of biological production in the Rhodes and Ionian basins of the eastern Mediterranean. J. Mar. Syst., 24: 277-298.

Pfannkuche, O. - 1985. The deep-sea meiofauna of the Porcupine Seabight and abyssal plain (NE Atlantic): population structure, distribution, standing stocks. Oceanol. Acta, 8: 343-353.

Pfannkuche, O. - 1993. Benthic response to the sedimentation of particulate organic matter at the BIOTRANS station $47^{\circ} \mathrm{N} 20^{\circ}$ W. Deep-Sea Res., 40: 135-149.

Pfannkuche, O., A. Boetius, K. Lochte, U. Lundgreen and H. Thiel. - 1999. Responses of deep-sea benthos to sedimentation patterns in the North-East Atlantic in 1992. Deep-Sea Res., 46: 573-596.

Poulos, S.E., P.G. Drakopoulos and M.B. Collins. - 1997. Seasonal variability in sea surface oceanographic conditions in the Aegean Sea (eastern Mediterranean): an overview. J. Mar. Syst., 13: 225-244.

Poulos, S.E., G. Chronis, M.B. Collins and V. Lykousis. - 2000. Thermaikos Gulf Coastal System, NW Aegean Sea: an overview of water/sediment fluxes in relation to air-land-ocean interactions and human activities. J. Mar. Syst., 25: 47-76.

Price, N.B., T. Brand, J.M. Pates, S. Mowbray, A. Theocharis, G. Civitarese, S. Miserocchi, S. Heussner and F. Lindsay. - 1999 Horizontal distributions of biogenic and lithogenic elements of suspended particulate matter in the Mediterranean Sea. Prog. Oceanogr., 44: 191-218

Psarra, S., A. Tselepides and L. Ignatiades. - 2000. Primary productivity in the oligotrophic Cretan Sea (NE Mediterranean): seasonal and interannual variability. Prog. Oceanogr., 46: 187-204.

Rabitti, S., F. Bianchi, A. Boldrin, L. Daros, G. Socal and C. Totti. - 1994. Particulate matter and phytoplankton in the Ionian Sea. Oceanol. Acta, 17: 297-307.

Reisig, J.M. - 1982. Nodeluum moniliforme, Ammomarginulina hadalensis and Favocassidulina subfavus, three new species of recent deep water benthic foraminifera. J. Paleontol., 56: 977 982.

Roether, W., B.B. Manca, B. Klein, D. Bregant, D. Georgopoulos, V. Beitzel, V. Kovacevic and A. Luchetta. - 1996. Recent changes in the Eastern Mediterranean deep water. Science, 271: 333-335.

Rowe, G.T. - 1971. Benthic biomass and surface productivity. In: J.D. Costlow (ed.), Fertility of the Sea, pp. 442-454. Gordon Breach, New York.

Sardà, F., G. D’Onghia, C.Y. Politou, J.B. Company, P. Maiorano and K. Kapiris. - 2004. Deep-sea distribution, biological and ecological aspects of Aristeus antennatus (Risso, 1816) in the western and central Mediterranean Sea. Sci. Mar., 68(Suppl.3): 117-127.

Siokou-Frangou, I., M. Bianchi, U. Christaki, E.D. Christou, A. Giannakourou, O. Gotsis, L. Ignatiades, K. Pagou, P. Pitta, S. Psarra, E. Souvermezoglou, F. van Wambeke and V. Zervakis. -2002 . Carbon flow in the planktonic food web along a gradient of oligotrophy in the Aegean Sea (Mediterranean Sea). $J$. Mar. Syst., 33-34: 335-353.

Smith, K.L., M.B. Laver and N.O. Brown. - 1983. Sediment community oxygen consumption and nutrient exchange in the central and eastern North Pacific. Limnol. Oceanogr., 28: 882-898.

Soetaert, K., C. Heip and M. Vincx. - 1991. The meiobenthos along a Mediterranean deep-sea transect off Calvi (Corsica) and in Adjacent Canyon. P.S.Z.N.I: Mar. Ecol., 12: 227-242.

Soetaert, K., J. Vanaverbeke, C. Heip, P.M.J. Herman, J.J. Middelburg, A. Sandee and G. Duineveld. - 1997. Nematode distribution in ocean margin sediments of the Goban Spur (northeast Atlantic) in relation to sediment geochemistry. DeepSea Res., 44: 1671-1683.

Souvermezoglou, E., E. Hatzigeorgiou, I. Pampidis and K. Siapsali. - 1992. Distribution and seasonal variability of nutrients and dissolved oxygen in the northeastern Ionian Sea. Oceanol. Acta, 15: $585-594$

Theocharis, A., E. Balopoulos, S. Kioroglou, H. Kontoyiannis and A. Iona. - 1999. A synthesis of the circulation and hydrography 
of the south Aegean Sea and the straits of the Cretan Arc (March 1994-January 1995). Prog. Oceanogr., 44: 469-509.

Theocharis, A., Klein, B., Nittis, K. and W. Roether - 2002. Evolution and status of the Eastern Mediterranean Transient (1997-1999). J. Mar. Syst., 33-34: 91-116.

Thiel, H. - 1983. Meiobenthos and nanobenthos of the deep-sea. In: G. Rowe (ed.). Deep-Sea Biology, pp. 167-230. Wiley, New York.

Tietjen, J.H. - 1992. Abundance and biomass of metazoan meiobenthos in the deep sea. In: G.T. Rowe and V. Pariente (eds.), Deep-sea food chains and the global carbon cycle, pp. 45-62. Kluwer Academic Publishers

Tietjen, J.H., J.W. Deming, G.T. Rowe, S. Macko and R.J. Wilke. - 1989. Meiobenthos of the Hatteras Abyssal Plain and Puerto Rico Trench: abundance, biomass and associations with bacteria and particulate fluxes. Deep-Sea Res., 36: 1567-1577.

Tselepides, A. and A. Eleftheriou. - 1992. South Aegean (Eastern Mediterranean) continental slope benthos: macrofaunal-environmental relathionships. In: G.T. Rowe and V. Pariente (eds.) Deep-sea food chains and the global carbon cycle, pp. 139-156. Kluwer Academic Publishers.

Tselepides, A., T. Polychronaki and N. Lampadariou. - 2000a. Distribution of meiofauna and sedimentary organic matter in the deep eastern Mediterranean Sea. 9th Deep-Sea Biology Symposium. National University of Ireland, Galway, Ireland, 26-30 June.
Tselepides, A., V. Zervakis, T. Polychronaki, R. Danovaro and G. Chronis. - 2000b. Distribution of nutrients and particulate matter in relation to the prevailing hydrographic features of the Cretan Sea (NE Mediterranean). Prog. Oceanogr., 46: (2-4), 113-142.

Tselepides A., Papadopoulou N., Podaras D., Plaiti W. and D. Koutsoubas - 2000c. Macrobenthic community structure over the continental margin of Crete (South Aegean Sea, NE Mediterranean). Prog. Oceanogr., 46: (2-4), 401-428.

Tselepides A. and N. Lampadariou - 2004. Deep-sea meiofaunal community structure in the Eastern Mediterranean: are trenches benthic hot spots? Deep-Sea Res., 51: 833-847.

Turley, C.M., M. Bianchi, U. Christaki, P. Conan, J.R. Harris, S. Psarra, G. Ruddy, E.D. Stutt, A. Tselepides and F. van Wambeke. - 2000. Relationship between primary producers and bacteria in an oligotrophic sea - the Mediterranean and biogeochemical implications. Mar. Ecol. Prog. Ser., 193: 11-18.

Yacobi, Y.Z., T. Zohari, N. Kress, A. Hecht, R.D. Robarts, M Waiser, A.M. Wood and W.K.W. Li. - 1995. Chlorophyll distribution throughout the southeastern Mediterranean in relation to the physical structure of the water mass. J. Mar. Syst., 6: 179189.

Yentsch, C.S. and D.W. Menzel. - 1963. A method for the determination of phytoplankton chlorophyll and phaeophytin by fluorescence. Deep-Sea Res., 10: 221-231 
